\title{
Pyrolysis of pine wood and characterisation of solid and liquid products
}

\author{
Barnasan Purevsuren*, Otgonchuluun Dashzeveg, Ariunaa Alyeksandr, Narangerel Janchig, \\ Jargalmaa Soninkhuu
}

Institute of Chemistry and Chemical Technology, Mongolian Academy of Sciences, Peace avenue, MAS $4^{\text {th }}$ building, Bayanzurkh district, Ulaanbaatar 13330, Mongolia

*Corresponding author: bpurevsuren.icct@gmail.com; ORCID ID:0000-0003-3077-9644

Received: 16 October 2018; revised: 01 February 2019; accepted: 12 February 2019

\section{ABSTRACT}

Pyrolysis of pine wood was carried out at different temperatures and the yields of solid (biochar), liquid (tar and pyrolysed water) and gas products were determined. Temperature around $500^{\circ} \mathrm{C}$ was determined as an optimal heating temperature of pyrolysis and approximately $27.1 \%$ hard residue (biochar), $21.46 \%$ tar, $20.04 \%$ pyrolysed water and $31.30 \%$ gas were obtained by pyrolysis. The thermal stability indices of pine wood are relatively low, which are indications of its low thermal stability and high yield of volatile matter $\left(\mathrm{V}^{\mathrm{daf}}=90.3 \%\right)$. The thermal stability indices of pyrolysis of solid residue show that it is characterised by a very high thermal stability than its initial sample, for example, there was an increase of $\mathrm{T}_{5} \% 7.7$ and $\mathrm{T}_{15} \% 3.8$ times. The chemical composition of pyrolysed tar of pine wood has also been determined. Were obtained 4 different fractions with varying boiling temperature ranges of pine wood pyrolysed tar and have determined the yields of each fraction. Neutral tar was analysed by GC/MS and 20 aliphatic compounds, 25 aromatic compounds and 18 polar compounds were determined.
\end{abstract}

Keywords: pine wood, pyrolysis, biochar, aliphatic, aromatic and polar fractions

\section{INTRODUCTION}

Mongolia is a country with a scant wood resource, as only $8-9 \%$ of the northern part of the country's territory is covered by forest. Pine trees (pine wood) are one of most commonly distributed trees in the northern forest regions and a huge amount of wastes deposited nearby a wood processing factory. Therefore, wood wastes should be an object for utilization.

The pyrolysis of different organic natural raw materials [1] such as different kinds of coal [2, 3], oil shale [4, 5], casein [6 - 8] and waste materials, including plastics [9], animal bone [10, 11], cedar shell bone [12], sawdust [13] and so on has been carried out for many years now. Therefore, pyrolysis has been chosen as an important method for processing pine wood for producing valuable solid, liquid and gas products.

The solid product of thermal decomposition is a hard residue with porous structure and can be used it as an activated carbon through chemical or physical activation. The condensed liquid product consists of tar and pyrolysed water. They are a complex raw material for different kinds of organic substances such as organic acids, organic bases, phenolic compounds, neutral oils, naphthalene, antrazine and so on. The non-condensed gas products can be used as gas fuel after purification.

\section{EXPERIMENTAL}

The pine wood was crushed into small pieces $3-6$ $\mathrm{mm}$ in size and the analytical sample was prepared by powdering the wood into small particles size $<0.2 \mathrm{~mm}$ in a steel mill. Powdered and dried pine wood produced a solid product with a yellowish shade.

Analytical sample preparation (MNS 2719-2001), proximate and ultimate analysis of pine wood were performed according to Mongolian National Standards MNS 656-79 (moisture content), MNS 652-79 (ash yield), MNS 654-79 (volatile matter yield).

The elemental composition of pine wood was determined by micro analytical instrument 5E C2000, model CNH-analyser.

The FTIR spectra of pine wood were obtained on a Nicolet 20-PC FTIR spectrometer with Csl optics and

(C) The Author(s). 2018 Open access. This article is distributed under the terms of the Creative Commons Attribution 4.0 International License (http://creativecommons.org/licenses/by/4.0/), which permits unrestricted use, distribution, and reproduction in any medium, provided you give appropriate credit to the original author(s) and the source, provide a link to the Creative Commons license, and indicate if changes were made. 
DTGS detector. The $\mathrm{KBr}$ disc contained $0.5 \%$ finely ground shell sample. All the spectra were measured in the frequency range of 4000 to $400 \mathrm{~cm}^{-1}$, and 32 scans were taken for every sample.

Thermogravimetric analysis of pine wood was carried out in TG/DTA7200, (Hitachi, Japan). Conditions of analysis were as follows: Sample weight $5-10 \mathrm{mg}$, heating temperature range $20-1150{ }^{\circ} \mathrm{C}$, heating rate $40{ }^{\circ} \mathrm{C} \mathrm{min}^{-1}$, carrier gas-nitrogen, crucible made by Pt-Rh. Small-scale pyrolysis experiments of pine wood samples were performed in a laboratory quartz retort (tube) which could process $1 \mathrm{~g}$ of pine wood sample. The retort was placed in a horizontal electric tube furnace. A chrome-alumel thermocouple was immersed in the tube furnace to measure the actual heating temperature. Pyrolysis experiments have been carried out at different temperatures $200-700{ }^{\circ} \mathrm{C}$ with constant heating rate of $20^{\circ} \mathrm{C} \mathrm{min}-1$. First of all, the quartz retort with pine wood sample was heated, for example, to $600{ }^{\circ} \mathrm{C}$ with heating rate of $20^{\circ} \mathrm{C} \mathrm{min}{ }^{-1}$, and kept at $700^{\circ} \mathrm{C}$ for 80 minutes. The retort was connected with a thermostable glass tube heated also in a tube furnace at $80^{\circ} \mathrm{C}$ for collecting tar. This tube was also connected with an air-cooled glass vessel for collecting pyrolysed water. The glass vessel for pyrolysed water was connected with a thin glass tube for non-condensable gases. The yields of pyrolysed products, including solid residue (biochar), tar (condensed liquid product) and pyrolysed water were determined by weighing, and the yield of gases were determined basing on their differences.

The preparative-scale pyrolysis experiments of pine wood sample were performed in a vertical cylindrical laboratory retort of stainless steel with a capacity containing $1000 \mathrm{~g}$ of sample. The retort was placed in an electric furnace (model SNOL, Russia) with a maximum temperature of $950{ }^{\circ} \mathrm{C}$. A chrome-alumel thermocouple was immersed in the pine wood bed to measure the actual heating temperature. The retort was connected with an air-cooled iron tube and watercooled laboratory glass condenser and a collection vessel for the condensate of liquid product (pitch and pyrolysed water). The non-condensable gases were isolated and removed through a thin glass tube after passing through water-cooled condenser. The experiments were carried out to at a temperature of $900^{\circ} \mathrm{C}$ and the heating rate was $20^{\circ} \mathrm{C} \mathrm{min} \mathrm{m}^{-1}$. The yields of products, including solid residue (biochar), tar and pyrolysed water were determined by weighing, and the yield of gases by the differences obtained.

The liquid product of pine wood pyrolysis consists of tar and pyrolysed water. They form an unmixed two layers and can be separated easily by separating in a glass funnel. The upper layer is tar (viscous liquid) with black-brown colour and an unpleasant smell. The bottom layer is pyrolysed water (non-viscous liquid) with an unpleasant smell and yellowish in colour. The final cleaning of tar from the pyrolysed water was mixed with thermally treated $\mathrm{CaCl}_{2}$ and through separation (filtering or centrifuging). The yellowish pyrolysed water has a specific gravity of $0.9227 \mathrm{~g} \cdot \mathrm{CM}^{-3}$ and solid residue of $7.2 \%$ after evaporation in room temperature.

The pyrolysed pine wood samples (10-15 g) were placed in a quartz tube and flowed with nitrogen to remove the oxygen and heated until $800{ }^{\circ} \mathrm{C}$ and processed (activated) with heated water steam for 120 minutes.

\section{Sample separation and GC/MS analysis}

Acid and base separation: The sample of pyrolysed tar of pine wood $(1 \mathrm{ml})$ was dissolved in hexane (10 $\mathrm{ml}$ ) and extracted with three $20 \mathrm{ml}$ portions of aqueous sulphuric acid $(10 \%)$ to isolate the basic components and with three $20 \mathrm{ml}$ portions of aqueous sodium hydroxide $(10 \%)$ to isolate the acidic components. The organic phase (neutral fraction) was washed with distilled water, dried with sodium sulphate and hexane was evaporated. The combined sulphuric acid extracts were neutralized with alkali and extracted with three $20 \mathrm{ml}$ portions of dichloromethane and the organic phases (basic fraction) were dried and evaporated to the required concentration for GC/MS analysis. The combined sodium hydroxide extracts were acidified and extracted in a similar fashion to yield the acidic fraction. Chemical class separation: An aliquot $(0.2 \mathrm{ml})$ of the neutral fraction was applied to column separation. The glass column $(10 \times 1.0 \mathrm{~cm})$ was packed with activated alumina $(4.0 \mathrm{~g})$ and elution was performed by using hexane, toluene and dichloromethane. Hexane (10 ml) was used as an eluent to separate alkanes and alkenes (aliphatic compounds). The second fraction (aromatics) was eluted in $10 \mathrm{ml}$ of toluene. The third fraction (polar compounds) was eluted with $10 \mathrm{ml}$ dichloromethane. Aliquots of three fractions were freed of solvents by evaporation at room temperature $\left(20^{\circ} \mathrm{C}\right)$ and dissolved in dichloromethane to a suitable concentration for $\mathrm{GC} /$ MS analysis.

GC/MS analysis: TSQ 8000 Trace 1310 Gas Chromatography-Mass spectrometer was used for identifying and quantifying organic compounds contained in the fractions. Capillary column; TR- $5 \mathrm{~ms} 60 \mathrm{~m} \times 0.25$ $\mathrm{mm} \times 0.25 \mu \mathrm{m}$, Oven program: $50^{\circ} \mathrm{C} \mathrm{min}{ }^{-1}, 8^{\circ} \mathrm{C} \mathrm{min}{ }^{-1}$ to $320^{\circ} \mathrm{C}$, hold time at $320^{\circ} \mathrm{C} 30 \mathrm{~min}$; Injection volume $1 \mu \mathrm{l}$, Carrier gas and its flow: He $1.5 \mathrm{ml} \cdot \mathrm{min}^{-1}$. Inlet temperature $250{ }^{\circ} \mathrm{C}$. MS transfer line temperature 250 ${ }^{\circ} \mathrm{C}$. Ion source temperature $250^{\circ} \mathrm{C}$. Scanned masses 45 - 550 AMU.

\section{RESULTS AND DISCUSSION}

The proximate (basic technical characteristics) analysis of pine wood and its pyrolysed solid (hard residue) product have been performed and the results are given in Table 1. Table 1 shows that there is very little amount of ash $0.56 \%$ in the pine wood waste, indicating that it is a pure organic raw material. When it is heated in the absence of oxygen, the organic mass is easy to decompose, which then releases a good amount of volatile substances. The volatile matter content of the 
Table 1. The results of proximate analysis of pine wood and its pyrolysed hard residue

\begin{tabular}{|c|c|c|c|c|c|c|c|}
\hline \multirow[t]{2}{*}{ Sample } & \multirow{2}{*}{$\begin{array}{l}\text { Moisture, } \\
\%, \mathbf{W}^{\mathrm{a}}\end{array}$} & \multicolumn{2}{|c|}{ Ash, \% } & \multicolumn{2}{|c|}{$\begin{array}{c}\text { Volatile } \\
\text { matters, \% }\end{array}$} & \multicolumn{2}{|c|}{$\begin{array}{l}\text { Calorific value, } \\
{\mathrm{Kcal} \cdot \mathrm{kg}^{-1}}^{-1}\end{array}$} \\
\hline & & $A^{a}$ & $A^{d}$ & $\mathbf{V}^{\mathbf{a}}$ & $\mathbf{V}^{\text {daf }}$ & $\mathbf{Q}^{\mathrm{a}}$ & $\mathbf{Q}^{\text {daf }}$ \\
\hline Pine wood & 5.2 & 0.56 & 0.6 & 85.1 & 90.3 & 5299 & 5623 \\
\hline $\begin{array}{l}\text { Hard } \\
\text { residue }\end{array}$ & 0.56 & 1.6 & 1.6 & 4.5 & 4.6 & 7989 & 8165 \\
\hline
\end{tabular}

pyrolysed hard residue of pine wood waste decreased 19.6 times compared with feed wood. Also the calorific value of the pyrolysed hard residue increased significantly as compared with the initial sample.

The ultimate analysis of pine wood analytical samples has been performed. The results show that the contents of $\mathrm{C}$ and $\mathrm{O}$ are highest or $50.5 \%$ and $42.52 \%, \mathrm{H}$ has a lower content or $6.7 \%, \mathrm{~N}$ and $\mathrm{S}$ have the lowest content or $0.1 \%$ and $0.18 \%$. High content of $\mathrm{O}$ is an indication that pine wood organic matter has large amount of oxygen containing functional groups and it is easy for thermal decomposition. The analytical sample of pine wood waste was a subject for FTIR analysis and the spectra is shown in Figure 1 and Table 2 respectively.

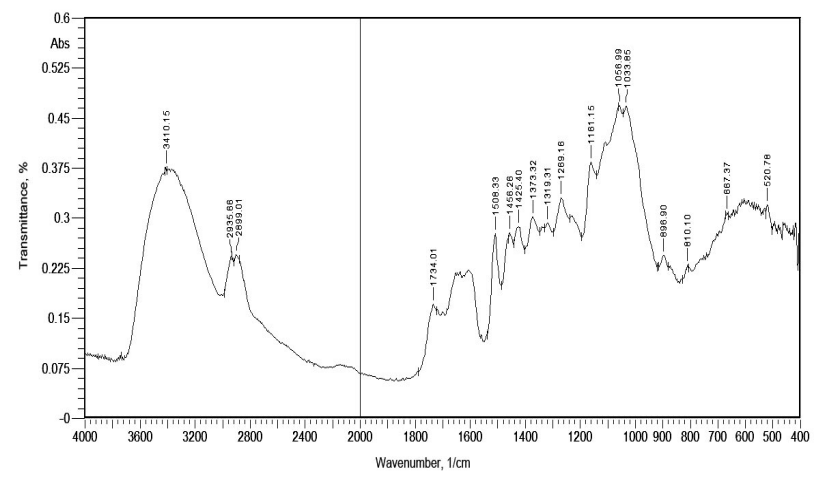

Fig. 1. The FTIR spectra of pine wood waste

Table 2. Functional groups and the modes of vibrations of various peaks

\begin{tabular}{|c|c|}
\hline $\begin{array}{l}\text { Adsorption } \\
\text { band }\left(\mathrm{cm}^{-1}\right)\end{array}$ & $\begin{array}{l}\text { Functional group with } \\
\text { mode of vibration }\end{array}$ \\
\hline 3410 & -OH groups \\
\hline $\begin{array}{l}2935,1456 \\
1425\end{array}$ & $\begin{array}{l}\text { Asymmetric stretching vibration of } \\
\text { aliphatic methylene groups } \mathrm{C}-\mathrm{H} \text { structure }\end{array}$ \\
\hline 2899,1373 & $\begin{array}{l}\text { Symmetric vibration of aliphatic methyl } \\
\text { groups } \mathrm{C}-\mathrm{H}\end{array}$ \\
\hline 1734 & Carboxyl acids \\
\hline 1508 & $\begin{array}{l}\text { Aromatic nucleus stretching vibration } \\
\text { band }(C=C)\end{array}$ \\
\hline 1319,1269 & Vibration of aromatic $\mathrm{C}-\mathrm{O}$ \\
\hline $\begin{array}{l}\text { 1161, 1056, } \\
1033\end{array}$ & Vibration of aromatic $-\mathrm{OH}$ groups \\
\hline 896,810 & aromatic $-\mathrm{C}=\mathrm{C}-$ groups \\
\hline
\end{tabular}

The FTIR spectra of pine wood waste in Figure 1 shows that it has a very intensive blunt peak at $3410 \mathrm{~cm}^{-1}$ for hydrogen from -OH groups. An adsorption band with middle intensity exists at 2935, 1456 and $1425 \mathrm{~cm}^{-1}$ for asymmetric stretching vibration of aliphatic methylene groups $\mathrm{C}-\mathrm{H}$ structure. A very week band at $1734 \mathrm{~cm}^{-1}$ is assigned to carboxyl acids. There are very little bands of the aromatic nucleus stretching vibration band $(\mathrm{C}=\mathrm{C})$ at $1508 \mathrm{~cm}^{-1}$, the aromatic -C-O-groups at $1319 \mathrm{~cm}^{-1}$ and $1269 \mathrm{~cm}^{-1}$, the aromatic $-\mathrm{OH}$ groups at $1161 \mathrm{~cm}^{-1}, 1056$ $\mathrm{cm}^{-1}$ and $1033 \mathrm{~cm}^{-1}$ and the aromatic $-\mathrm{C}=\mathrm{C}-$ groups at $700-900 \mathrm{~cm}^{-1}$.

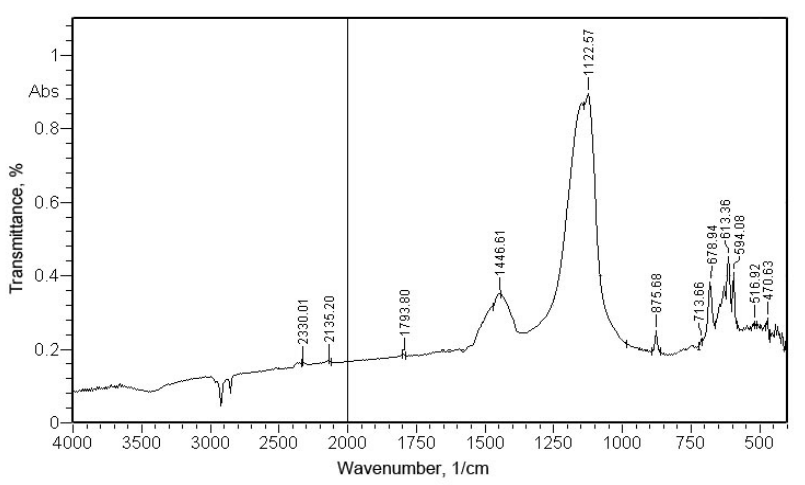

Fig. 2. The FTIR spectra of pine wood ash

Table 3. Functional groups and the modes of vibrations of various peaks

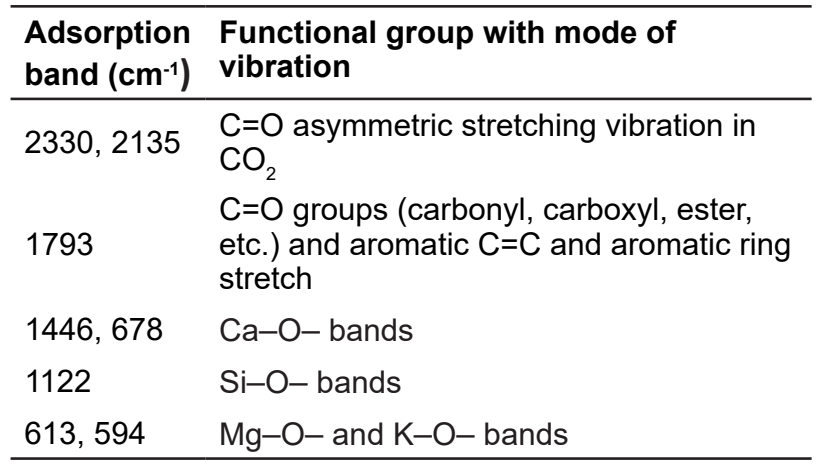

The FTIR spectra of pine wood ash is shown in Figure 2 and Table 3 respectively. The FTIR spectra of pine wood ash in Figure 2 is not very complicated because of few components and it shows that the most intensive peak is at $1122 \mathrm{~cm}^{-1}$ for $\mathrm{Si}-\mathrm{O}-$, peaks with middle intensities at 1446 and $678 \mathrm{~cm}^{-1}$ or $\mathrm{Ca}-\mathrm{O}-$, and peaks at 613 and $594 \mathrm{~cm}^{-1}$ for $\mathrm{Mg}-\mathrm{O}-$ and $\mathrm{K}-\mathrm{O}-$ bands, because the contents of $\mathrm{CaO}, \mathrm{K}_{2} \mathrm{O}, \mathrm{MgO}, \mathrm{SiO}_{2}$ are higher in Table 4. The ash of pine wood during analysis and pyrolysis experiments have been collected for the analysis of inorganic matters. Its chemical composition was determined by the XRF analysis and the results are given in Figure 3 and Table 4 respectively.

The data in Table 4 show that the content of $\mathrm{S}\left(\mathrm{SO}_{3}\right)$ is highest and the contents of $\mathrm{Ca}(\mathrm{CaO}), \mathrm{K}\left(\mathrm{K}_{2} \mathrm{O}\right), \mathrm{Mg}$ ( $\mathrm{MgO}), \mathrm{Si}\left(\mathrm{SiO}_{2}\right)$ are also high. The lower content have 


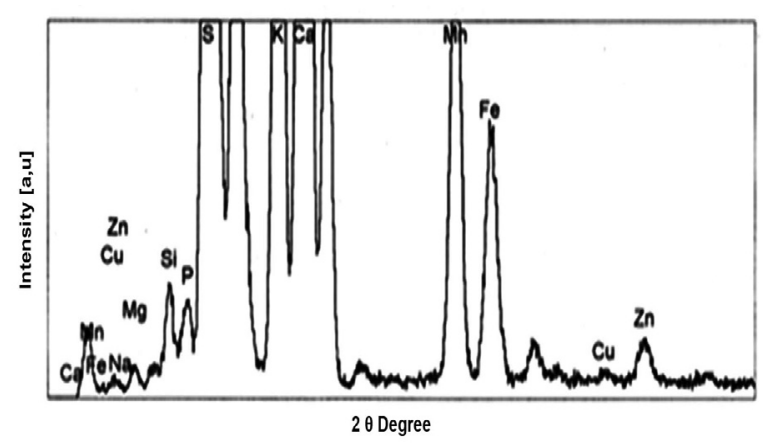

Fig. 3.The chemical composition of pine wood ash (wt \%)

Table 4. Chemical composition of pine wood ash (wt \%)

\begin{tabular}{llll}
\hline Element & \multicolumn{3}{l}{ Oxides } \\
\hline $\mathrm{Mg}$ & 4.876 & $\mathrm{MgO}$ & 8.085 \\
$\mathrm{Si}$ & 2.162 & $\mathrm{SiO}_{2}$ & 4.626 \\
$\mathrm{P}$ & 0.651 & $\mathrm{P}_{2} \mathrm{O}_{5}$ & 1.491 \\
$\mathrm{~S}$ & 17.781 & $\mathrm{SO}_{3}$ & 44.403 \\
$\mathrm{~K}$ & 7.906 & $\mathrm{~K}_{2} \mathrm{O}$ & 9.523 \\
$\mathrm{Ca}$ & 20.047 & $\mathrm{CaO}$ & 28.050 \\
$\mathrm{Mn}$ & 1.809 & $\mathrm{Mn}_{2} \mathrm{O}_{3}$ & 2.599 \\
$\mathrm{Fe}$ & 0.722 & $\mathrm{Fe}_{2} \mathrm{O}_{3}$ & 1.033 \\
\hline
\end{tabular}

$\mathrm{Mn}\left(\mathrm{Mn}_{2} \mathrm{O}_{3}\right)$, Fe $\left(\mathrm{Fe}_{2} \mathrm{O}_{3}\right)$ and $\mathrm{P}\left(\mathrm{P}_{2} \mathrm{O}_{5}\right)$. The value of ratio between sum oxides $\left(\mathrm{Fe}_{2} \mathrm{O}_{3}+\mathrm{CaO}+\mathrm{MgO}+\mathrm{K}_{2} \mathrm{O}\right) /$ $\left(\mathrm{SiO}_{2}\right)=10.09$ was more than one $(>1.0)$ and this value is an indication that the ash of pine wood has a basic (alkaline) character.

Also the ash of pine wood was a subject for XRD analysis and the results are given in Figure 4 and Table 5 respectively. The yield of most of the minerals determined in pine wood ash is given in Table 5.

The result of XRD analysis of pine wood ash reveals that the ash mostly consists of calcite $\left(\mathrm{CaCO}_{3}\right)$ and quartz $\left(\mathrm{SiO}_{2}\right)$. The analytical sample of pine wood was investigated by thermogravimetric analysis and the results are shown in Figure 5.

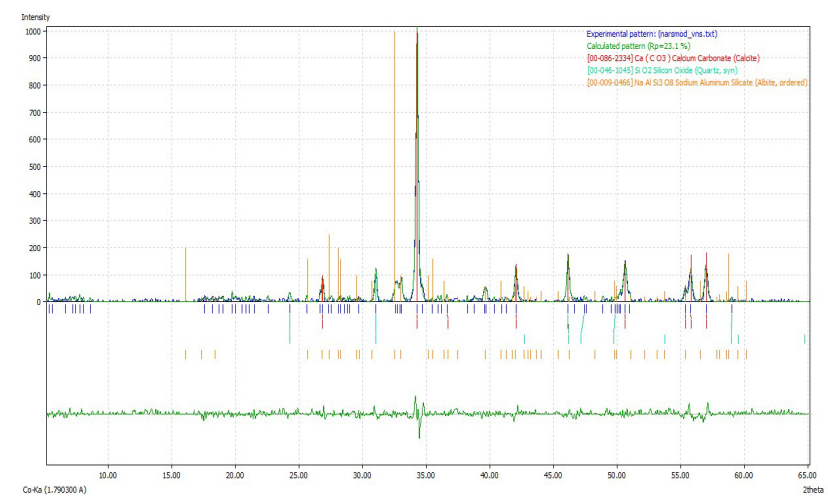

Fig. 4. Most of the minerals determined in pine wood ash by XRD analysis
Table 5. The yield of most of the minerals determined in pine wood ash

\begin{tabular}{lll}
\hline Minerals & $\begin{array}{l}\text { Chemical } \\
\text { formula }\end{array}$ & $\begin{array}{l}\text { Ash of pine } \\
\text { wood waste, \% }\end{array}$ \\
\hline Calcite & $\mathrm{CaCO}_{3}$ & 3.15 \\
Quartz & $\mathrm{SiO}_{2}$ & 3.41 \\
\hline
\end{tabular}

Heating of pine wood sample at $25-1100^{\circ} \mathrm{C}$ temperatures in nitrogen atmosphere revealed that the thermal decomposition of pine wood ended with about $10 \%$ weight loss and $90 \%$ hard residue at $1100{ }^{\circ} \mathrm{C}$ (Figure 5). The TG curve in Figure 5 consists of different temperature intervals such as $25-160{ }^{\circ} \mathrm{C}, 160-300{ }^{\circ} \mathrm{C}, 300-$ $400{ }^{\circ} \mathrm{C}$, and $400-1100^{\circ} \mathrm{C}$. In the first step $\left(25-160^{\circ} \mathrm{C}\right)$ the weight loss was due to releasing of some absorbed gas and moisture from pine wood sample. In the second step $\left(160-300{ }^{\circ} \mathrm{C}\right)$, the drying process resulted in the lowest weight loss. Intensive thermal decomposition of the organic matter of pine wood sample and formation of liquid (tar and pyrolysed water) and gas products starts in the third step $\left(300-400^{\circ} \mathrm{C}\right)$ during the pyrolysis. In the fourth step $\left(400-1100^{\circ} \mathrm{C}\right)$, the weight loss decreases intensively, which is an indication of the completion of the thermal decomposition and the start of carbonization of hard residue after intensive pyrolysis.

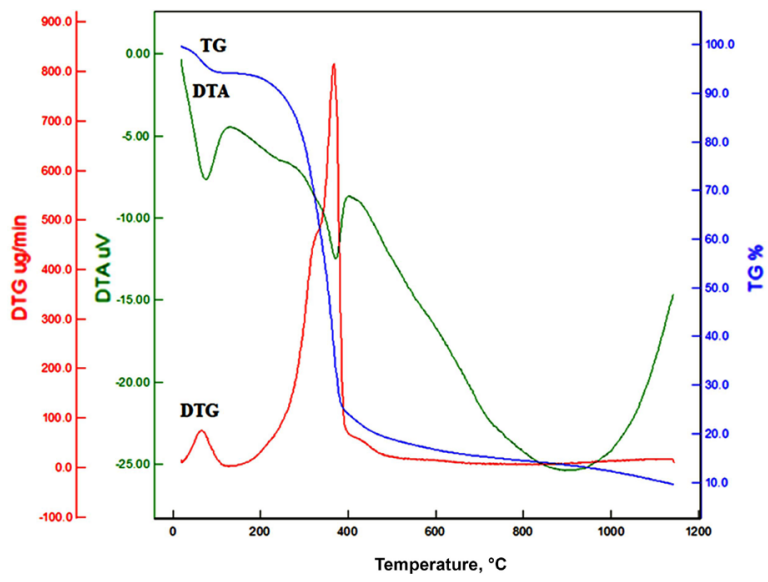

Fig. 5. Thermogravimetric curves (TG, DTA, DTG) of pine wood sample

TG analysis of the initial sample of pine wood and it's pyrolysed hard residue was repeated to determine their thermal stability indices and the resulting TG curves are shown in Figure 6 . On the basis of TG curves of pine wood and its pyrolysed hard residue, their thermal stability indices were calculated: $\mathrm{T}_{5} \%, \mathrm{~T}_{15} \%, \mathrm{~T}_{25} \%$ during thermal degradation in nitrogen atmosphere (Table 7). These indices are the temperatures in which the weight losses are 5, 15 and $25 \%$ respectively.

The thermal stability indices of pine wood in Table 6 are very low which are an indication of its lower thermal 


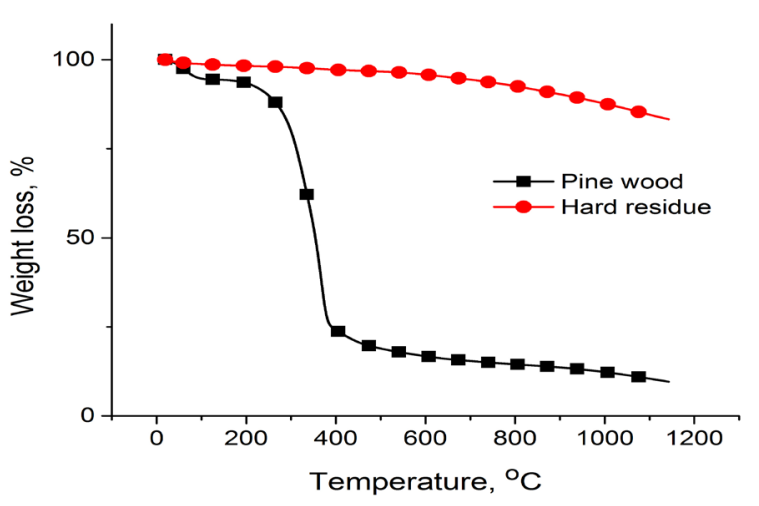

Fig. 6. TG curves of pine wood and its pyrolysed hard residue

stability and higher yield of volatile matter $\left(\mathrm{V}^{\text {daf }}=90.3 \%\right)$ as shown earlier in Table 1. The TG curves in Figure 2 and the thermal stability indices of pyrolysed hard residue show that they are characterised with very high thermal stability than their initial sample, which, for example, increased $\mathrm{T}_{5} \%$ 7,7 and $\mathrm{T}_{15} \%$ 3,8 times.

The pyrolysis experiments of pine wood were carried out in standard quartz retort at different heating temperatures with constant heating rate of $20^{\circ} \mathrm{C} \mathrm{min}-1$ and the yields of solid, liquid and gas products were determined. The results of the experiments are shown in Figure 7.

Table 6. The thermal stability indices $\left(\mathrm{T}_{5} \%, \mathrm{~T}_{15} \%\right.$, and $\mathrm{T}_{25} \%$ ) of shell

\begin{tabular}{lllc}
\hline \multirow{2}{*}{ Sample } & \multicolumn{3}{c}{ The thermal stability indices, ${ }^{\circ} \mathrm{C}$} \\
\cline { 2 - 4 } & $\mathrm{T}_{5} \%$ & $\mathrm{~T}_{15} \%$ & $\mathrm{~T}_{25} \%$ \\
\hline Pine wood & 84 & 280 & 311 \\
Hard residue & 651 & 1082 & - \\
\hline
\end{tabular}

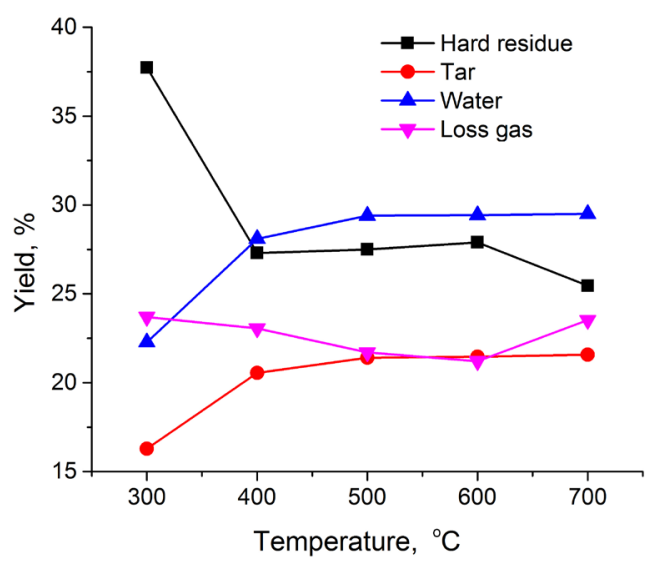

Fig. 7. The yields of solid, liquid and gas products of pyrolysis of pine wood
Figure 7 shows that the yield of condensed liquid product, such as tar and pyrolysed water and noncondensed gas product grew concurrently by increasing the heating temperature of pyrolysis. Only the yield of hard residue had decreased at the same time. The tar and hard residue, which were formed as a result of the pyrolysis, were the most important products. Certainly the yield of tar is lower at a lower temperature, because the thermal decomposition was not enough. The optimum temperature for pyrolysis of pine wood was selected at $500{ }^{\circ} \mathrm{C}$, where the yield of tar is high $-21.46 \%$.

The yields of pyrolysed products of pine wood obtained in this condition compared with the yields of other organic materials that have been investigated are given in Table 7.

Table 7. The yields of pyrolysed products of shell compared with other organic materials, $\%$

\begin{tabular}{lllll}
\hline Materials & $\begin{array}{l}\text { Hard } \\
\text { residue }\end{array}$ & Water & Gas & Tar \\
\hline Shell & 30.0 & 33.3 & 23.6 & 13.1 \\
Casein & 28.3 & 13.2 & 20.8 & 37.4 \\
Animal bone & 70.0 & 7.6 & 17.5 & 4.9 \\
Oil shale & 73.5 & 3.9 & 7.0 & 15.6 \\
Brown coal & 68.3 & 7.1 & 15.5 & 8.7 \\
Pine wood & 27.2 & 20.0 & 31.3 & 21.5 \\
\hline
\end{tabular}

Pine wood as a pure organic material, similarly like casein and shell, has a very low ash content and a very high organic matter, therefore, pine wood gives the lowest yield of hard residue and a higher yield of pyrolysed liquid (tar and pyrolysed water) and gas products (Table 7). In the case of animal bone the yields of hard residue and pyrolysed liquid products are similar or the same as oil shale and brown coal (Table 7 ), because of their higher mineral and lower organic matter contents [14].

Usually the solid product can be used as a carbonaceous material, smokeless fuel, activated carbon, while the liquid product can be used as a complex raw material for production of chemical substances. Gas products can be used as gas fuel after purifying them of $\mathrm{N}$ and $S$ containing gases and for this reason precisely, the solid and liquid products of pyrolysis of pine wood have been characterised. The technical characteristics of the hard residue (solid product) by pyrolysis of pine wood are given in Table 8 . An activation process at $800^{\circ} \mathrm{C}$ with preheated water steam for different time of heating was used for preparing an activated carbon, based on pyrolysed hard residue of pine wood. Activation results in formation of black carbonized solid material with visually high porosity structures. The yield and the ash content of initial pine wood, pyrolysed hard residue and activated carbon samples have been determined. The 
Table 8. Main characteristics of pyrolysed hard residue and activated carbon samples of pine wood

\begin{tabular}{llllllll}
\hline Sample & $\begin{array}{l}\text { Heating } \\
\text { temperature }\end{array}$ & $\begin{array}{l}\text { Time of } \\
\text { heating, } \mathbf{m i n}\end{array}$ & $\begin{array}{l}\text { Yield, } \\
\%\end{array}$ & $\begin{array}{l}\text { lodine } \\
\text { adsorption, } \%\end{array}$ & $\begin{array}{l}\text { Methylene blue } \\
\text { adsorption, mg/g }\end{array}$ & $\begin{array}{l}\text { Ash, } \\
\mathbf{A}^{\mathrm{d}}, \%\end{array}$ & $\begin{array}{l}\text { Volatile matter, } \\
\text { Vdaf, } \%\end{array}$ \\
\hline Initial pine wood & - & - & - & 5.4 & 10.0 & 0.6 & 85.1 \\
Hard residue & - & - & - & 10.0 & 23.9 & 1.6 & 4.6 \\
Activated carbon & $800^{\circ} \mathrm{C}$ & 100 & 89.5 & 17.0 & 84.0 & 4.2 & 4.9 \\
$\begin{array}{l}\text { of pyrolysed hard } \\
\text { residue of pine wood }\end{array}$ & $800^{\circ} \mathrm{C}$ & 140 & 88.0 & 18.4 & 108.0 & 5.6 & 5.2 \\
& $800^{\circ} \mathrm{C}$ & 180 & 86.5 & 39.9 & 119.0 & 5.8 & 5.9 \\
\hline
\end{tabular}

adsorption value of methylene blue and iodine were determined for the evaluation of the adsorption capacity of the activated carbons, hard residue and initial pine wood and the results are given in Table 8.

Table 8 shows that the optimal heating time at $800{ }^{\circ} \mathrm{C}$ was chosen at 180 minutes, in which the adsorption capacity is higher. At this optimal condition of activation the adsorption of methylene blue increased and the adsorption of iodine also increased more than 2 times.

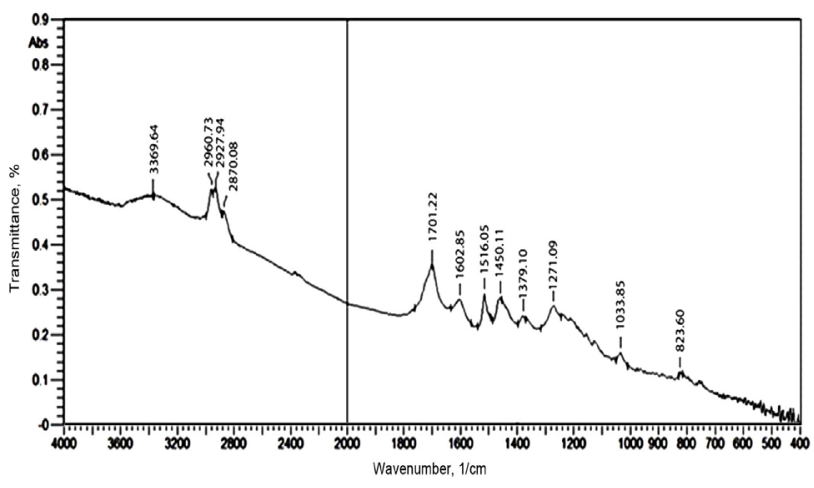

Fig. 8. The FTIR spectrum of pyrolysed tar of pine wood

Table 9. Functional groups and the modes of vibrations at various peaks

\begin{tabular}{ll}
\hline $\begin{array}{l}\text { Adsorption } \\
\left.\text { band } \mathbf{( c m}^{-1}\right)\end{array}$ & Functional group with mode of vibration \\
\hline 3369 & -OH groups \\
2960,2927, & $\begin{array}{l}\text { Asymmetric stretching vibration of aliphatic } \\
\text { methylene groups C-H structure }\end{array}$ \\
1450 & $\begin{array}{l}\text { Symmetric vibration of aliphatic methyl } \\
\text { groups C-H }\end{array}$ \\
2870,1379 & $\begin{array}{l}\text { C=O groups (carbonyl, carboxyl, ester, etc.) } \\
\text { and aromatic C=C and aromatic ring stretch }\end{array}$ \\
1701,1602, & $\begin{array}{l}\text { aliphatic ether (C-O-C), phenolic and } \mathrm{OH} \\
\text { stretching }\end{array}$ \\
1271,1033 & aromatic $-\mathrm{C}=\mathrm{C}-$ groups \\
\hline 823 &
\end{tabular}

Also the contents of ash and volatile matter increased and these results show that there was intensive carbonization process, releasing more volatile matters at $800{ }^{\circ} \mathrm{C}$ temperature with a longer duration (180 min) of heating.

As mentioned above, the condensed liquid product (tar) is petroleum like raw material which is multifunctional and a multi-component product. Therefore, we decided to carry out a much more detailed investigation on the condensed liquid product. First the tar was analysed by FTIR and the spectra are shown in Figure 8 and Table 9 respectively. The FTIR spectra of pyrolysed tar of pine wood have very week peaks of aromatic $-\mathrm{C}=\mathrm{C}-$ groups at $823 \mathrm{~cm}^{-1}$ and week peak of aromatic $-\mathrm{OH}$ groups at $1033 \mathrm{~cm}^{-1}$. Peaks with higher intensity were observed for C-O-C groups at $1271 \mathrm{~cm}^{-1}$ and for aromatic ring stretch at $1516 \mathrm{~cm}^{-1}$. Peaks with higher intensity were observed for asymmetric stretching vibration of aliphatic methylene groups C-H structure at 2960, 2927 and $1450 \mathrm{~cm}^{-1}$ and for $-\mathrm{COOH}$ groups at $1701 \mathrm{~cm}^{-1}$. Weak peaks for aromatic $\mathrm{C}=\mathrm{C}$ at $1602 \mathrm{~cm}^{-1}$ for symmetric vibration of aliphatic methyl groups $\mathrm{C}-\mathrm{H}$ at 2870, 1379 $\mathrm{cm}^{-1}$ and broad peak for $-\mathrm{OH}$ groups at $3369 \mathrm{~cm}^{-1}$ are observed in this FTIR spectra of pyrolysed tar of pine wood. The FTIR spectra of pyrolysed tar of pine wood show that the tar is a multi-functional complex organic material. More tar has been collected by using bigger scale retort at the optimal condition of pyrolysis.

The pyrolysed water was removed by the method mentioned in the experiments. The collected and purified tar was subject to chemical group analysis for determining its chemical composition and the results are given in Table 10. Pre-asphaltanes have the highest content, while free carbons and asphaltanes have a mediocre content and organic acids, and the organic bases and phenolic compounds have the lowest contents. These results show that the tar is a mixture of chemical compounds formed during thermal decomposition (pyrolysis) of the pine wood organic matter.

Table 10. Chemical composition in group organic compounds of pyrolysed tar

\begin{tabular}{llllll}
\hline Pre-asphaltene & Free carbons & Organic bases & Organic acids & Phenols & Asphaltenes \\
\hline 64.70 & 11.00 & 5.50 & 5.50 & 3.50 & 9.80 \\
\hline
\end{tabular}


The collected and purified tar was subjected to atmospheric distillation in order to obtain several fractions with different boiling temperature ranges and the yields of fractions are given in Table 11.

Table 11. The yields of fractions with different boiling temperature ranges

\begin{tabular}{lllll}
\hline Fractions & Colour & $\begin{array}{l}\text { Boiling } \\
\text { temperature } \\
\text { range, }{ }^{\circ} \mathrm{C}\end{array}$ & $\begin{array}{l}\text { Yield of } \\
\text { fraction, } \\
\%\end{array}$ & $\begin{array}{l}\text { Refraction } \\
\text { index }\end{array}$ \\
\hline $\begin{array}{l}\text { Light } \\
\text { fraction }\end{array}$ & Yellow & $>180$ & 10.6 & 1.473 \\
$\begin{array}{l}\text { Middle } \\
\text { fraction }\end{array}$ & Brown & $180-220$ & 7.0 & 1.516 \\
$\begin{array}{l}\text { Heavy } \\
\text { fraction }\end{array}$ & $\begin{array}{l}\text { Black } \\
\text { brown }\end{array}$ & $220-250$ & 17.9 & 1.522 \\
$\begin{array}{l}\text { Residue of } \\
\text { distillation }\end{array}$ & Black & $<250$ & 61.05 & \\
\hline
\end{tabular}

The residue of distillation has the highest yield and it is a bitumen-like product with a black colour. The yields of heavy and light fractions are higher and the yield of middle fraction is lower. These fractions can be used as gasoline (light fraction), diesel (middle fraction), neutral oil products (heavy fraction) and bitumen after removing organic acids, organic bases and phenolic compounds. GC/MS analysis of purified tar, after the removal of pyrolysed water, was used for a much more detailed investigation to determine the chemical composition of pyrolysed tar of pine wood.

Organic acids and organic bases removed from the tar and the residual neutral part of the tar were analysed

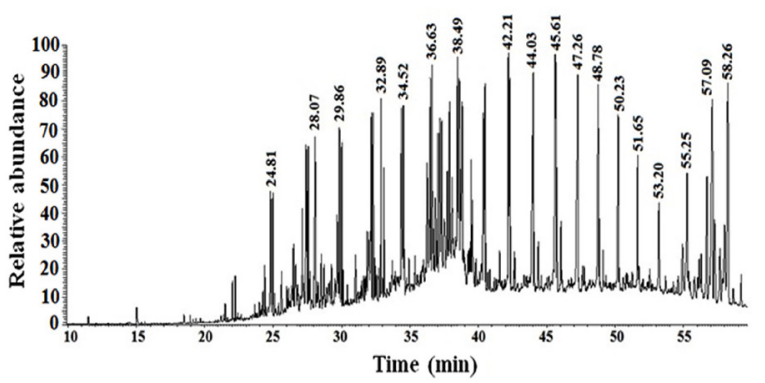

Fig. 9. GC/MS analysis of hexane soluble aliphatic fraction

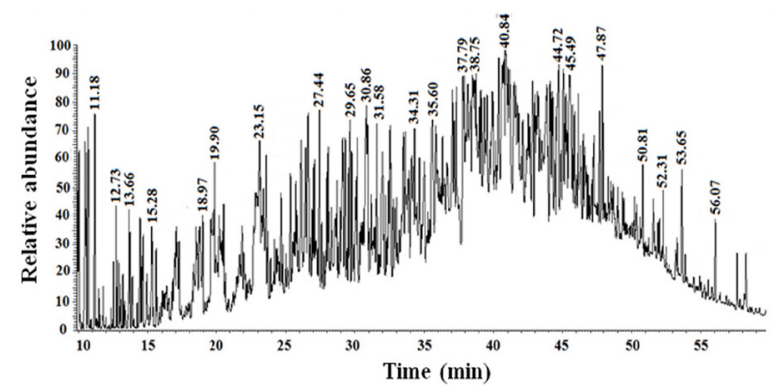

Fig. 10. GC/MS analysis of toluene soluble aromatic fraction

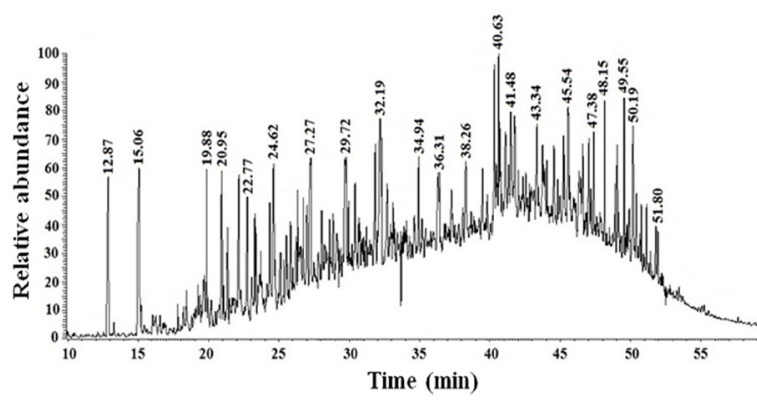

Fig. 11. GC/MS analysis of dichloromethane soluble polar fraction

Table 12. Total contents of organic group compounds determined by GC/MS analysis

\begin{tabular}{ll}
\hline Organic compound class & Yield, \% \\
\hline Aliphatic fraction & \\
Aliphatic compounds & 46.42 \\
Aromatic compounds & 3.81 \\
Aromatic fraction & \\
Aliphatic compounds & 2.4 \\
Aromatic compounds & 59.77 \\
Polar fraction & \\
Polar compounds & 46.44 \\
\hline
\end{tabular}

by GC/MS. Chromatograms, including aliphatic fraction (Figure 9), aromatic fraction (Figure 10), polar fraction (Figure 11) are given. Table 12 shows the identified organic compounds and their contents. 20 aliphatic compounds, 25 aromatic compounds and 18 polar compounds with total contents of $46.42 \%$ aliphatic compounds in aliphatic fraction, $59.77 \%$ aromatic compounds in aromatic fraction, $46.44 \%$ polar compounds in polar fraction have been identified as a main result of GC/MS analysis of neutralized pyrolysed tar of pine wood.

\section{CONCLUSIONS}

1. On the basis of proximate, ultimate, FTIR and XRD analyses, it can be concluded that the pine wood is a raw material with a high amount of organic matter and very low ash, which consists mostly of calcite $\left(\mathrm{CaCO}_{3}\right)$ and quartz $\left(\mathrm{SiO}_{2}\right)$.

2. The results of pyrolysis experiment of pine show that the yield of condensed liquid product, such as tar and pyrolysed water and non-condensed gas product increased by raising the heating temperature of pyrolysis. Only the yield of solid or hard residue decreased at the same time. The optimum temperature for pyrolysis of pine wood was selected at $500{ }^{\circ} \mathrm{C}$, in which the yield of tar is highest at $21.46 \%$.

3. The optimal heating time of activation of pyrolysed residue of pine wood at $800{ }^{\circ} \mathrm{C}$ was chosen at $180 \mathrm{~min}$. At this optimal condition of activation, the 
adsorption of methylene blue increased and the adsorption of iodine increased more than 2 times up to $119.0 \mathrm{mg} \cdot \mathrm{g}^{-1}$ and $39.9 \%$ respectively.

4. The determined yields of fractions with different boiling temperature ranges of pine wood pyrolysed tar show that the residue of distillation has the highest yield, the yields of heavy and light fractions are higher and the yield of middle fraction is lower. These fractions can be used as gasoline (light fraction), diesel (middle fraction), neutral oil products (heavy fraction) and bitumen after removing organic acids, organic bases and phenolic compounds.

\section{REFERENCES}

1. Purevsuren B., Davaajav Ya., Batbileg S., Ariunaa A., et al. (2016) Investigation on pyrolysis of some organic raw materials. Mong. J. Chem., 17(43) 5-13. doi:10.5564/mjc.v17i43.739

2. Avid B., Purevsuren B., Born M., Dugarjav J., et al. (2002) Pyrolysis and TG analysis of the Shivee Ovoo coal Mongolia. J. Therm. Anal. Calori., 68, 877-885. doi:10.1023/A:1016130203799

3. Ariunaa A., Bao-Qing Li., Wen Li., Purevsuren B., Munkhjargal Sh., et al. (2007) Coal pyrolysis under synthesis gas, hydrogen and nitrogen. J. Fuel Chem. Tech., 35(1), 1-4. doi:10.1016/S1872$\underline{\text { 5813(07)60007-3 }}$

4. Avid B., Purevsuren B., Dugarjav J. (2000) Pyrolysis and thermogravimetrical investigation of the Mongolian Khoot oil shale. Oil shale., 17(3), 241-251. http://www.kirj.ee/public/oilshale/17-3-4. $\underline{\text { html }}$

5. Purevsuren B., Ochirbat P. (2016) Comparative study of pyrolysis and thermal dissolution of Estonian and Mongolian Khoot oil shales. Oil shale., 33(4), 329-339. doi:10.3176/oil.2016.4.02
6. Purevsuren B., Davaajav Ya. (2001) Thermal analysis of casein. J. Therm. Anal. Calori., 65, 147-152. https://link.springer.com/ article/10.1023/A:1011532819792.

7. Purevsuren B., Davaajav Ya. (2001) Investigation on pyrolysis of casein. J. Therm. Anal. Calori., 66, 743-748. doi:10.1023/A:1013135920477

8. Purevsuren B., Avid, B., Tesche B., Davaajav Ya. (2003) A biochar from casein and its properties. J. Mater. Scien., 38(11), 2347-2351. doi:10.1023/A:1023980429410

9. Purevsuren B., Davaajav Ya., Karaca F., Morgan T.J., et al. (2009) Pyrolysis of waste polypropylene and characterization of the tar. Europ. J. Mass Spect., 15(1), 23-33. doi:10.1255/ejms.975

10. Purevsuren B., Avid B., Narangerel J., Gerelmaa T., Davaajav Ya. (2004) Investigation the pyrolysis products from animal bone. J. Mater. Scien., 39, 737-740. doi:10.1023/B:JMSC.0000011545.51724. $\underline{\mathrm{ad}}$

11. Purevsuren B., Avid B., Gerelmaa T., Davaajav Ya., et al. (2004) The characterization of tar from pyrolysis of animal bones. J. Fuel., 83, 799-805. doi:10.1016/i.fuel.2003.10.011

12. Purevsuren B., Davaajav Ya., Batbileg S., Ganzorig Ch. (2012) Investigation on pyrolysis of shell. Proc. Mong. Acad. Scien., 52, 2(202), 45-52.

13. Munkhjargal Sh., Purevsuren B. (1998) Products of pyrolysis of wood wastes. Reports of the Institute of Chemistry and Chemical Technology, Mongolian Academy of Sciences, Ulaanbaatar, 25-28. 